\title{
PHYSIOLOGICAL POTENTIAL OF IRRIGATED RICE SEEDS TREATED WITH AMINO ACIDS AND UNDER SALT STRESS
}

\author{
POTENCIAL FISIOLÓGICO DE SEMENTES DE ARROZ IRRIGADO TRATADAS \\ COM AMINOÁCIDOS E SUBMETIDAS A ESTRESSE SALINO
}

\begin{abstract}
Elisa Souza LEMES' ${ }^{1}$, Leticia DIAS ${ }^{2}$; Thaís D'Avila ROSA ${ }^{3}$; Vânia Marques GEHLING ${ }^{4}$; Sandro de OLIVEIRA ${ }^{5}$; André Oliveira de MENDONÇA ${ }^{6}$; Géri Eduardo MENEGHELLO ${ }^{7}$

1. Engenheira Agrônoma, Doutoranda em Ciência e Tecnologia de Sementes, Universidade Federal de Pelotas - UFPel, Pelotas, RS, Brasil. lemes.elisa@yahoo.com.br; 2. Engenheira Agrônoma, Doutoranda em C\&T de Sementes, UFPel, Pelotas, RS, Brasil; 3. Engenheira Agrônoma, Doutoranda em C\&T de Sementes, UFPel, Pelotas, RS, Brasil; 4. Bióloga, Doutoranda em C\&T de Sementes, UFPel, Pelotas, RS, Brasil; 5. Engenheiro Agrônomo, Doutorando em C\&T de Sementes, UFPel, Pelotas, RS, Brasil; 6. Biólogo, Doutorando em C\&T de Sementes, UFPel, Pelotas, RS, Brasil; 7. Engenheiro Agrônomo, Doutor em C\&T de Sementes, UFPel, Pelotas, RS, Brasil.
\end{abstract}

\begin{abstract}
Salt stress in rice plants affects growth, development and crop yield. However, seed treatment can reduce the deleterious effects caused by salt stress. The use of amino acids in agriculture has increased, both in Brazil and in other countries, due to higher productivity and provide better quality of plants treated with amino acids. The objective of this study was to evaluate the effect of amino acid coating on the physiological potential of rice seeds under salt stress. The experimental design was a completely randomized three-way factorial design with two batches of seeds, two levels of amino acid treatment (with or without amino acid) and five salt concentrations (0.0, 25.0, 50.0, 75.0 and $100.0 \mathrm{mM}$ ) with four replicates. The physiological quality of seeds was assessed by a germination test, first germination count, cold test, accelerated aging, seedling shoot and root lengths, and dry weight of shoots and roots. It is concluded that the seed treatment with amino acids results in better physiological performance of rice seeds when subjected to salt stress, which affects negatively the physiological quality of seeds.
\end{abstract}

KEYWORDS: Oryza sativa L. Salinity. Germination. Vigor. Coating.

\section{INTRODUCTION}

Rice (Oryza sativa L.) is the third mostproduced cereal in the world, second only to wheat and corn (USDA, 2013). Brazil is among the top ten producers of rice, the largest producer outside Asia (VAN NGUYEN; FERRERO, 2006). One of the main rice irrigation systems is to flood the rice fields, which can lead to soil salinization in fields with poor drainage, especially in cropping areas that use sea water. Therefore salinity is one of the most significant environmental constraints on rice production (LIMA, 2008).

Salt stress in rice plants can be triggered by the presence of excess salts in the soil, or by introduction of the cropping system through irrigation water. In both cases, a large concentration of salts affects growth, development, and productivity of the culture (BENITEZ et al., 2010), due to the increased osmotic pressure of the soil solution and the accumulation of excess ions in plant tissue. Excess ions may be toxic or cause other nutrient deficiencies, or in alteration of the nutritional status of the plants, for the absorption abilities and nutritional requirements (SCIVITTARO et al., 2009). Thus, seed treatment may reduce the deleterious effects caused by salt stress.

According to Bays et al. (2007), the primary requirement of an increasingly competitive market is to add value to the seeds, using production methods and technologies such as seed treatment. Currently, treatment is used to incorporate materials such as fungicides, micronutrients, pesticides, plant hormones and polymers which improve the performance of seeds and seedlings and even later stages of culture.

Amino acids are organic molecules formed by a carbon $(\alpha)$ connected to four chemical groups: one amine group $\left(\mathrm{NH}_{2}\right)$, a carboxylic group $(\mathrm{COOH})$, a hydrogen atom and a side group (radical); these organizational units can meet and form larger molecules called proteins, which are formed from 20 amino acids (ROSSETTI, 2012). In plants, amino acids serve as precursors of chlorophyll, polyamides important in early cell proliferation, lignin which gives rise to the formation of woody tissues, and indol acetic acid which is a natural auxin (plant growth regulator). Amino acids also participate in the synthesis of other amino acids and chlorophyll, and act as organic nitrogen reserves, regulate water balance, have anti-stress and anti-senescence effects, act in 
the formation of cell walls, play an important role in hormone metabolism, and induce the mechanism of viral resistance (PRIYACHEM, 2014a).

The application of amino acids in crops is not intended to meet the protein synthesis needs of plants but to activate physiological metabolism (FLOSS; FLOSS, 2007). The use of amino acids in agriculture has increased, both in Brazil and in other countries, due to the higher yields and better quality of a variety of cultured plants (BRANDÃO, 2007). In addition, other benefits of using amino acids that have been cited by Brandão (2007), are metabolic balance, improved photosynthesis, decreased phytotoxicity of some pesticides, increased tolerance to pests and diseases, better absorption and translocation of nutrients applied to the leaves improving the development and strength of the root system, better hormonal regulation, improved tolerance to water stress and frost, increased flowering, and increased quality of the harvested products.

The aim of this study was to evaluate the effect of amino acids applied to seeds on the physiological performance of batches of rice seeds submitted to salt stress.

\section{MATERIAL AND METHODS}

The research was conducted in the Flavio Farias Rocha Seed Testing Laboratory (LDAS) of the Department of Plant Science, Eliseu Maciel Faculty of Agriculture (FAEM) of the Federal University of Pelotas (UFPel). Seeds of two batches of rice seeds of the cultivar IRGA 424 were used, considered moderately tolerant to salinity.

The experimental design was completely randomized with three factorial arrangements of: 1 ) Batches - lot 1 and lot 2; 2) Amino acid treatment with or without amino acid; 3) Salt treatment -0.0 , $25.0,50.0,75.0$ and $100.0 \mathrm{mM}$; with four replications.

The seeds were coated with the commercial product Amino Plus $\AA$ and the ColorSeed $\AA$ polymer at doses of $400 \mathrm{~mL} 100 \mathrm{~kg}-1$ of seed and $300 \mathrm{~mL}$ $100 \mathrm{~kg}-1$ of seed, respectively. The use of the polymer in the treatment was to improve adhesion of the amino acid product to the seed. The proportion of the spray volume was maintained at $1200 \mathrm{~mL} 100 \mathrm{~kg}^{-1}$ of seed by adding water, and this proportion was maintained in the control treatment of water and polymer only. Seed coating was done using a manual method described by Nunes (2005) which mixes seeds and products in plastic bags (3 L). The products were applied directly to the bottom of the plastic bag and spread to a height of about 15 centimeters, after which $0.1 \mathrm{~kg}$ of seeds was placed inside the plastic bag and shaken vigorously for three minutes. After mixing seeds and products the bags were opened for the seeds to dry at room temperature for a period of 24 hours.

The product Amino Plus $®$ has 14 amino acids: alanine $(1.164 \%)$; arginine $(0.189 \%)$; aspartic acid $(1.943 \%)$; glutamic acid $(3.316 \%)$; glycine $(0.202 \%)$; isoleucine $(0.171 \%)$; leucine $(0.268 \%)$; lysine $(0.240 \%)$; phenylalanine $(0.143 \%)$; serine $(0.179 \%)$; threonine $(0.188 \%)$; tryptophan $(0.175 \%)$; tyrosine $(0.122 \%)$; valine $(0.288 \%)$; and nutrients $\mathrm{N}(11 \%)$ and $\mathrm{K}_{2} \mathrm{O}(1 \%)$ (AJINOMOTO, 2013).

After treatment, seeds were evaluated with the following laboratory tests:

Germination $(G)$ test: conducted with 200 seeds, with four replicates of 50 seeds per experimental unit. Germitest paper was used as a germination substrate. The germitest paper was moistened with distilled water (control) and with four concentrations of sodium chloride. The volume of water applied to the paper was 2.5 times the weight of dry paper. The germitest paper rolls were kept in a germination chamber at $25^{\circ} \mathrm{C}$ and the number seedlings were counted 14 days after sowing, with results expressed as a percentage of normal seedlings (BRASIL, 2009).

First germination count (FGC): The number of normal seedlings was counted in each replicate five days after the start of the test. The results were expressed as a percentage of normal seedlings.

Cold test $(C T)$ : Four replicates of 50 seeds for each experimental unit were uniformly distributed on germitest paper rolls, moistened with distilled water (control) and with four concentrations of sodium chloride. The volume of water applied to the paper was 2.5 times the weight of dry paper. The germitest rolls were immediately placed in plastic bags, which were sealed and kept in a BOD chamber at a temperature of $10^{\circ} \mathrm{C} \pm 1^{\circ} \mathrm{C}$ for seven days (CICERO; VIEIRA, 1994). At the end of this period, the rolls were transferred to a germination chamber and maintained under the same conditions as the germination test, assessing the percentage of normal seedlings after five days.

Accelerated aging (AA): Seeds were uniformly spread over a metal screen suspended in a germination box containing $40 \mathrm{ml}$ distilled water. The boxes were capped and kept in BOD chamber at $41^{\circ} \mathrm{C}$ for $72 \mathrm{~h}$ (MARCOS FILHO, 1999). Then the seeds were germinated as for the germination test and seedlings counted on the fifth day. The 
results were expressed as a percentage of normal seedlings.

Seedling shoot length (SL) and root length (RL): Four replicates of 20 seeds for each experimental unit were crisscrossed in two rows in the upper third of the germitest paper, moistened with distilled water (control) and with four concentrations of sodium chloride. The volume of water applied to the paper was 2.5 times the weight of dry paper. The paper rolls were kept in a germination chamber at $25^{\circ} \mathrm{C}$. The total seedling length and the shoot length of ten randomly selected seedlings were measured five days after sowing using a ruler graduated in millimeters. The root length was estimated by subtracting the shoot length from the total seedling length. The average lengths of shoots and roots were determined by summing the readings of each replication and dividing by the number of seedlings evaluated, according to the methodology described by Nakagawa (1999).
Seedling dry weight (SDW): Shoots and roots were separated with a scalpel, placed in paper bags and dried in an air-circulating oven at $60^{\circ} \mathrm{C}$ for 72 hours. After this period, the samples were placed to cool in a desiccator and weighed on an analytical balance. Results are expressed in mg seedling-1 (NAKAGAWA, 1999).

The experimental data were subjected to analysis of variance. Significant results were further explored using "t-test" for qualitative factors and polynomial regression analysis for quantitative factors. Significance was set at the $5 \%$ probability level.

\section{RESULTS AND DISCUSSION}

There was a significant interaction between lots and amino acid salt concentration for the first count of germination, cold test and root dry weight (Table 1).

Table 1. Results of the first count of germination tests (FGC), cold test (CT) and root dry weight (RDW) for two lots of rice seeds with and without amino acid treatment and subjected to different degrees of salt stress with sodium chloride.

\begin{tabular}{cccccccc}
\hline \multirow{2}{*}[\mathrm{NaCl}]{$(\mathrm{mM})$} & \multirow{2}{*}{ Amino acid } & \multicolumn{2}{c}{ FCG $(\%)$} & \multicolumn{2}{c}{ CT $(\%)$} & \multicolumn{2}{c}{ RDW $(\mathrm{mg})$} \\
\cline { 3 - 8 } & & Lot 1 & Lot 2 & Lot 1 & Lot 2 & Lot 1 & Lot 2 \\
\hline \multirow{2}{*}{0} & With & $74 \mathrm{Aa}^{1}$ & $70 \mathrm{Aa}$ & $61 \mathrm{Aa}$ & $67 \mathrm{Aa}$ & $1.52 \mathrm{Aa}$ & $1.10 \mathrm{Ab}$ \\
& Without & $71 \mathrm{Aa}$ & $68 \mathrm{Aa}$ & $59 \mathrm{Aa}$ & $64 \mathrm{Aa}$ & $1.44 \mathrm{Aa}$ & $1.01 \mathrm{Ab}$ \\
\hline \multirow{2}{*}{25} & With & $72 \mathrm{Aa}$ & $66 \mathrm{Ab}$ & $57 \mathrm{Ab}$ & $64 \mathrm{Aa}$ & $1.39 \mathrm{Aa}$ & $1.24 \mathrm{Ab}$ \\
& Without & $70 \mathrm{Aa}$ & $61 \mathrm{Bb}$ & $58 \mathrm{Aa}$ & $63 \mathrm{Aa}$ & $1.24 \mathrm{Ba}$ & $1.20 \mathrm{Aa}$ \\
\hline \multirow{2}{*}{50} & With & $71 \mathrm{Aa}$ & $66 \mathrm{Aa}$ & $56 \mathrm{Aa}$ & $57 \mathrm{Aa}$ & $0.96 \mathrm{Ab}$ & $1.23 \mathrm{Aa}$ \\
& Without & $62 \mathrm{Ba}$ & $55 \mathrm{Bb}$ & $54 \mathrm{Aa}$ & $55 \mathrm{Aa}$ & $1.08 \mathrm{Aa}$ & $0.95 \mathrm{Ba}$ \\
\hline \multirow{2}{*}{75} & With & $65 \mathrm{Aa}$ & $65 \mathrm{Aa}$ & $58 \mathrm{Aa}$ & $55 \mathrm{Aa}$ & $0.88 \mathrm{Ba}$ & $0.89 \mathrm{Aa}$ \\
& Without & $50 \mathrm{Ba}$ & $54 \mathrm{Ba}$ & $44 \mathrm{Bb}$ & $55 \mathrm{Aa}$ & $1.07 \mathrm{Aa}$ & $0.83 \mathrm{Ab}$ \\
\hline \multirow{2}{*}{100} & With & $33 \mathrm{Ab}$ & $56 \mathrm{Aa}$ & $51 \mathrm{Aa}$ & $49 \mathrm{Aa}$ & $0.66 \mathrm{Aa}$ & $0.69 \mathrm{Aa}$ \\
& Without & $23 \mathrm{Bb}$ & $31 \mathrm{Ba}$ & $27 \mathrm{Bb}$ & $39 \mathrm{Ba}$ & $0.70 \mathrm{Aa}$ & $0.55 \mathrm{Bb}$ \\
\hline
\end{tabular}

1 Means followed by the same capital letter in columns within each concentration do not differ by test $\mathrm{t}(\mathrm{p} \leq 0.05)$. Means followed by the same lowercase letter in rows for each response variable do not differ by test $\mathrm{t}(\mathrm{p} \leq 0.05)$.

For the first count of germination lot 1 had more normal seedlings than lot 2 at a salt concentration of $25 \mathrm{mM}$, while lot 2 had a higher percentage of normal seedlings at the highest concentration used. Other differences were not significant (Table 1). Without the use of amino acid, lot 1 had more normal seedlings at salt concentrations of 25 and $50 \mathrm{mM}$, but at concentrations of 75 and $100 \mathrm{mM}$ lot 2 had a higher percentage of normal seedlings. The same behavior was observed for lot 2 at the concentrations of 25 , 50, 75 and $100 \mathrm{mM}$ (Table 1). These results may be related to the activation of enzymes that promote germination using amino acid and may favor the best performance of the seeds during stress (PRIYACHEM, 2014b). Lima et al. (2005), using BRS Bojurú and IAS 12-9 Formosa (salt-tolerant) and BRS Agrisul and BRS 6 Chui (salt-sensitive) rice treated with sodium chloride, found a decrease in germination in both cultivars with increasing salinity, and concluded that salinity affected the development of normal seedlings and decreases the viability and vigor of seeds. 
In general seedling germination in after treatment with cold and amino acids did not differ between lots within each level of salinity, except at a salt concentration of $25 \mathrm{mM}$ when lot 2 had more normal seedlings than lot 1 (Table 1). For lot 1 , the use of amino acid promoted an increase in vigor at salt concentrations of 50, 75 and $100 \mathrm{mM}$, and for lot 2, there was an increase in vigor only at a salt concentration of $100 \mathrm{mM}$ (Table 1). Possibly the applied product has an anti-stress effect due to the action of amino acids in plant metabolism.

Using amino acid on lot 1 resulted in greater dry weight of roots at salt concentrations of 0 and 25 $\mathrm{mM}$, while at $50 \mathrm{mM}$ salt, lot 2 had heavier roots (Table 1). In the treatment without amino acid, lot 1 roots were heavier at salt concentrations of 0,75 and $100 \mathrm{mM}$. Within lot 1 root dry weight was greater with amino acid only at a salt concentration of 25 $\mathrm{mM}$. However, a salt concentration of $75 \mathrm{mM}$ without amino acid generated seedlings with heavier root dry matter. In lot 2 , treatment with amino acid resulted in greater root dry matter at salt concentrations of 50 and $100 \mathrm{mM}$ (Table 1).

In lot 1 , the proportion of normal seedlings germinated on day five showed a quadratic relationship with salt concentration for both amino acid treatments (Table 2). There was an increase in the percent normal seedlings up to concentrations of $25.74 \mathrm{mM}$ in seeds treated with amino acid and to
$15 \mathrm{mM}$ in seeds without amino acid treatment. Treatment with amino acid resulted in an increase of $4.9 \%$ at the point of maximum, while absence of amino acid resulted in an increase of only $1.49 \%$ (Table 2). This demonstrates that coating with amino acid increased the tolerance of seeds to salinity to a maximum tolerable salinity, but there was a sharp drop in the percentage of normal seedlings at greater salinity. In lot 2 treatments with and without amino acid the relationship between percent normal seedlings and salinity is a decreasing linear model with reductions of $0.119 \%$ (+ amino acid) and $0.318 \%$ ( - amino acid) for each unit increase in the salt concentration (Table 2). Similarly, Deuner et al. (2011), working with seed from different cowpea genotypes, found that an increase in soil salt concentration reduced first and final germination counts.

Increasing salinity produced similar responses in the cold test in treatments with and without amino acid in both batches, with a reduction in the percent of normal seedlings of $0.078 \%$ (+ amino acid) and $0.177 \%$ (- amino acid) (lot 1), and $0.318 \%$ (+ amino acid) and $0.233 \%$ ( - amino acid) (lot 2) for every unit increase in the salt concentration (Table 2). Treatment with amino acid in lot 1 resulted in a less marked decrease in the effect of increasing salinity compared to the seed of lot 1 without amino acid.

Table 2. Regression Analysis of the first count of germination, cold test and root dry weight of two lots of rice seeds with and without amino acid treatment and subjected to different concentrations of sodium chloride.

\begin{tabular}{|c|c|c|c|c|c|}
\hline Amino acid & Lot & $\begin{array}{c}\text { Equation } \\
\mathrm{Y}= \pm \mathrm{ax}^{3} \pm b \mathrm{~b}^{2} \pm \mathrm{cx} \pm \mathrm{d}\end{array}$ & $\begin{array}{c}\mathrm{P} \\
\left(\mathrm{b}_{\mathrm{ix}}\right)\end{array}$ & $\mathrm{R}^{2}$ & $\begin{array}{c}\mathrm{Y} \\
\text { Expected }\end{array}$ \\
\hline \multirow{3}{*}{ With } & & \multicolumn{4}{|c|}{ First count of germination (\%) } \\
\hline & Lot 1 & $-0.0074 x^{2}+0.381 x+71.5$ & * & 0.94 & 76.4 \\
\hline & Lot 2 & $-0.119 x+70.5$ & * & 0.79 & 70.5 \\
\hline \multirow{2}{*}{ Without } & Lot 1 & $-0.0066 x^{2}+0.198 x+69.9$ & & 0.99 & 75.6 \\
\hline & Lot 2 & $-0.318 x+69.6$ & * & 0.83 & 69.6 \\
\hline & & \multicolumn{4}{|c|}{ Cold Test (\%) } \\
\hline \multirow{2}{*}{ With } & Lot 1 & $-0.078 x+60.35$ & \multirow[t]{2}{*}{ * } & 0.67 & 60.4 \\
\hline & Lot 2 & $-0.318 x+64.25$ & & 0.85 & 64.3 \\
\hline \multirow{2}{*}{ Without } & Lot 1 & $-0.177 x+67.15$ & \multirow[b]{2}{*}{ * } & 0.98 & 67.2 \\
\hline & Lot 2 & $-0.233 x+66.90$ & & 0.85 & 66.9 \\
\hline \multirow{3}{*}{ With } & & \multicolumn{4}{|c|}{ Root Dry Weight (mg) } \\
\hline & Lot 1 & $-0.0089 x+1.527$ & 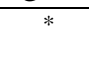 & 0.95 & 1.527 \\
\hline & Lot 2 & $-0.0066 x+1.436$ & * & 0.92 & 1.436 \\
\hline \multirow{2}{*}{ Without } & Lot 1 & $-0.0001 x^{2}+0.0068 x+1.120$ & \multirow[b]{2}{*}{ * } & 0.94 & 75.8996 \\
\hline & Lot 2 & $-9 \mathrm{E}^{-5} \mathrm{x}^{2}+0.0042 \mathrm{x}+1.046$ & & 0.92 & 76.3611 \\
\hline
\end{tabular}

*Significant at $5 \%$ probability. 
The relationship of the root dry weight to salinity (Table 2) decreased linearly in both lots treated with amino acid, decreasing 0.0089 (lot 1) and 0.0066 (lot 2) $\mathrm{mg}$ per plant for each unit of increased salt concentration. In treatment without amino acid root dry weight was related to salt concentration in a quadratic model for both lots (Table 2), with the point of maximum efficiency at concentrations of $34 \mathrm{mM}$ (lot 1) and $23 \mathrm{mM}$ (lot 2) . Likewise, Moraes et al. (2005) observed that bean seedlings had small increases in dry mass at the lower osmotic concentrations, reducing the most negative potential.

A significant interaction between amino acid treatment and batches of seed in germination (Table 3) showed that lot 1 had better germination than lot 2 only in the treatment without amino acid. The use of amino acids in seed treatment promoted more germination in both lots. Application of amino acids to bean seeds showed no positive effect on seed germination. but the seeds had greater viability (KIKUTI; TANAKA, 2007).

Table 3. Percentage of normal seedlings obtained from germination test $(\mathrm{G})$ of two lots of rice seeds with and without amino acid treatment and subjected to different concentrations of sodium chloride.

\begin{tabular}{ccc}
\hline \multirow{2}{*}{ Amino acid } & \multicolumn{2}{c}{$\mathrm{G}(\%)$} \\
\cline { 2 - 3 } & Lot 1 & Lot 2 \\
\hline With & $191 \mathrm{Aa}$ & $91 \mathrm{Aa}$ \\
Without & $87 \mathrm{Ba}$ & \\
\hline C.V. $(\%)$ & & 2.3 \\
\hline
\end{tabular}

1 Means followed by the same capital letter in columns within each concentration do not differ by test $\mathrm{t}(\mathrm{p} \leq 0.05)$. Means followed by the same lowercase letter in rows for each response variable do not differ by test $\mathrm{t}(\mathrm{p} \leq 0.05)$.

There was an interaction between batches and salt concentration in accelerated aging tests, root length and dry weight of shoots (Table 4). Lot 1 was more vigorous than lot 2 at concentrations of 25 and $50 \mathrm{mM}$, but at concentrations of 0 and $100 \mathrm{mM}$, lot 2 was more vigorous. Lot 1 had longer roots at a concentration of $50 \mathrm{mM}$ but lot 2 had longer roots at zero salinity. Lot 1 had greater shoot dry mass than lot 2 at salinities of 50, 75 and $100 \mathrm{mM}$. It should be noted that the effects of salinity vary with species and plant growth stage, as well as with the type, duration and intensity of stress (LARCHER, 2000).

Table 4. Results of accelerated aging tests (AA), root length (RL) and dry weight of shoot (DWS) for two lots of rice seeds with and without amino acid treatment and subjected to different concentrations of sodium chloride.

\begin{tabular}{|c|c|c|c|c|c|c|}
\hline \multirow{2}{*}[\mathrm{NaCl}]{$(\mathrm{mM})$} & \multicolumn{2}{|c|}{$\mathrm{AA}(\%)$} & \multicolumn{2}{|c|}{$\mathrm{RL}(\mathrm{cm})$} & \multicolumn{2}{|c|}{ DWS (mg) } \\
\hline & Lot 1 & Lot 2 & Lot 1 & Lot 2 & Lot 1 & Lot 2 \\
\hline 0 & $181 \mathrm{~b}$ & $85 \mathrm{a}$ & $7.3 \mathrm{~b}$ & $7.7 \mathrm{a}$ & $1.60 \mathrm{a}$ & $1.68 \mathrm{a}$ \\
\hline 25 & $84 \mathrm{a}$ & $79 \mathrm{~b}$ & $7.1 \mathrm{a}$ & $7.3 \mathrm{a}$ & $1.38 \mathrm{a}$ & $1.32 \mathrm{a}$ \\
\hline 50 & $83 \mathrm{a}$ & $77 \mathrm{~b}$ & $6.9 \mathrm{a}$ & $6.5 \mathrm{~b}$ & $1.31 \mathrm{a}$ & $1.16 \mathrm{~b}$ \\
\hline 75 & $74 \mathrm{a}$ & $74 \mathrm{a}$ & $6.1 \mathrm{a}$ & $6.1 \mathrm{a}$ & $1.06 \mathrm{a}$ & $0.74 \mathrm{~b}$ \\
\hline 100 & $69 \mathrm{~b}$ & $71 \mathrm{a}$ & $5.4 \mathrm{a}$ & $5.3 \mathrm{a}$ & $0.73 \mathrm{a}$ & $0.60 \mathrm{~b}$ \\
\hline C.V. (\%) & \multicolumn{2}{|c|}{3.0} & \multicolumn{2}{|c|}{5.3} & \multicolumn{2}{|c|}{9.8} \\
\hline
\end{tabular}

1 Means followed by the same lowercase letter in rows for each response variable do not differ by test $\mathrm{t}(\mathrm{p} \leq 0.05)$.

Lots performed differently to increasing salinity. Lot 1 responded to salinity in a quadratic model with an increase in the percentage of normal seedlings up to a salinity of $24.3 \mathrm{mM}$, while lot 2 decreased linearly with increasing salinity by $0.129 \%$ for each unit increase in salt concentration (Table 5). Root length and dry weight of shoots behaved similarly, with linear reduction with increased salt concentration (Table 5). The slope of the decline in root length differed between lots, with reductions of 0.0194 (lot 1) and 0.0245 (lot 2) cm for every unit increase in the salt concentration. Similarly, shoot dry mass decreased by 0.0082 (lot 1) and 0.0109 (lot 2) $\mathrm{mg}$ per plant for each unit increase in salt concentration. 
Table 5. Regression Analysis of accelerated aging test, root length and dry weight of shoots of two lots of rice seedlings with and without amino acid treatment and subjected to different concentrations of sodium chloride.

\begin{tabular}{|c|c|c|c|c|}
\hline Batches & $\begin{array}{c}\text { Equation } \\
\mathrm{Y}= \pm a \mathrm{x}^{3} \pm b \mathrm{x}^{2} \pm \mathrm{cx} \pm \mathrm{d}\end{array}$ & $\begin{array}{c}P \\
\left(b_{i x}\right)\end{array}$ & $\mathrm{R}^{2}$ & $\begin{array}{c}\mathrm{Y} \\
\text { Expected }\end{array}$ \\
\hline & \multicolumn{4}{|c|}{ Accelerated Aging Test $(\%)$} \\
\hline Lot 1 & $-0.0028 x^{2}+0.1361 x+81.711$ & * & 0.96 & 76.4 \\
\hline \multirow[t]{2}{*}{ Lot 2} & $-0.129 x+83.475$ & $*$ & 0.95 & 83.5 \\
\hline & \multicolumn{4}{|c|}{ Root Length $(\mathrm{cm})$} \\
\hline Lot 1 & $-0.0194 x+7.5158$ & * & 0.91 & 7.5 \\
\hline \multirow[t]{2}{*}{ Lot 2} & $-0.0245 x+7.8024$ & * & 0.98 & 7.8 \\
\hline & \multicolumn{4}{|c|}{ Shoot Dry Weight (mg) } \\
\hline Lot 1 & $-0.0082 x+1.6283$ & 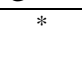 & 0.96 & 1.6283 \\
\hline Lot 2 & $-0.0109 x+1.6488$ & * & 0.98 & 1.6488 \\
\hline
\end{tabular}

*Significant at $5 \%$ probability.

There was a significant interaction of amino acid treatment and salt concentration for the root length and dry weight of shoots (Table 6). There was no difference in root length between amino acid treatments.

Table 6. Root length (RL) and dry weight of shoot (DWS) of two lots of rice seedlings, with and without amino acid treatment and subjected to different concentrations of sodium chloride.

\begin{tabular}{|c|c|c|c|c|}
\hline \multirow{3}{*}{$\mathrm{NaCl}(\mathrm{mM})$} & \multicolumn{2}{|c|}{$\mathrm{RL}(\mathrm{cm})$} & \multicolumn{2}{|c|}{ DWS (mg) } \\
\hline & \multicolumn{4}{|c|}{ Amino acid } \\
\hline & With & Without & With & Without \\
\hline 0 & $17.6 \mathrm{a}$ & $7.4 \mathrm{a}$ & $1.78 \mathrm{a}$ & $1.50 \mathrm{~b}$ \\
\hline 25 & $7.3 \mathrm{a}$ & $7.1 \mathrm{a}$ & $1.44 \mathrm{a}$ & $1.26 \mathrm{~b}$ \\
\hline 50 & $6.5 \mathrm{a}$ & $6.8 \mathrm{a}$ & $1.29 \mathrm{a}$ & $1.19 \mathrm{a}$ \\
\hline 75 & $5.6 \mathrm{~b}$ & $6.6 \mathrm{a}$ & $0.90 \mathrm{a}$ & $0.91 \mathrm{a}$ \\
\hline 100 & $5.2 \mathrm{a}$ & $5.4 \mathrm{a}$ & $0.71 \mathrm{a}$ & $0.62 \mathrm{a}$ \\
\hline C.V. (\%) & \multicolumn{2}{|c|}{5.3} & \multicolumn{2}{|c|}{9.8} \\
\hline
\end{tabular}

1 Means followed by the same lowercase letter in rows for each response variable do not differ by test $\mathrm{t}(\mathrm{p} \leq 0.05)$.

However, treatment with amino acid promoted shoot growth at salt concentrations of 0 and $25 \mathrm{mM}$ themselves, except for $75 \mathrm{mM}$ concentration of no treatment where the amino acid was higher (Table 6).

Both root length and dry weight of shoots decreased linearly with increasing salt concentration with and without amino acid (Table 7). Root length increased by $0.0257 \mathrm{~cm}$ (+ amino acid) and 0.0182 $\mathrm{cm}$ (- amino acid) for every unit increase in salt concentration. The negative effect of salinity on the growth and development of plants has been demonstrated by Torres et al. (2000) for cucumber, Duarte et al. (2006) for wheat and Garcia et al. (2007) for corn. A linear decrease was observed in the dry matter of leaves with increasing salinity in both treatments of 0.0107 (+ amino acid) and 0.0085
(- amino acid) $\mathrm{mg}$ for each unit increase in the salt concentration (Table 7).

A main effect of treatment with or without amino acid was observed in the accelerated aging and shoot length tests (Table 8). The main effect of salt concentration was also observed in the shoot length variable (Table 9). Treatment with amino acid gave higher values for both variables (Table 8). Seedlings with greater initial growth can generate more productive plants because of plants with high speed emergence and early growth use environmental resources early and therefore, usually have a competitive advantage (GUSTAFSON et al. 2004). Albuquerque et al. (2008) found that foliar sprays with products containing amino acids significantly favored growth of vine cuttings over control sprays. In turn, Light et al. (2010) obtained an increase in seedling height compared to controls 
by weekly applications of amino acids on a lettuce crop.

Increasing salt concentration caused a negative effect on shoot length; for each unit increase in salt concentration shoot length decreased by $0.0153 \mathrm{~cm}$ (Table 9 ).

Table 7. Regression Analysis of the root length and dry weight of shoot of two lots of rice seedlings with and without amino acid treatment and subjected to different concentrations of sodium chloride.

\begin{tabular}{|c|c|c|c|c|}
\hline Amino Acid & $\begin{array}{c}\text { Equation } \\
\mathrm{Y}= \pm \mathrm{ax}^{3} \pm \mathrm{bx} \mathrm{x}^{2} \pm \mathrm{cx} \pm \mathrm{d}\end{array}$ & $\begin{array}{c}\mathrm{P} \\
\left(\mathrm{b}_{\mathrm{ix}}\right)\end{array}$ & $\mathrm{R}^{2}$ & $\begin{array}{c}\mathrm{Y} \\
\text { Expected } \\
\end{array}$ \\
\hline & \multicolumn{4}{|c|}{ Root Length $(\mathrm{cm})$} \\
\hline With & $-0.0257 x+7.728$ & \multirow[t]{2}{*}{ * } & 0.97 & 7.7 \\
\hline Without & $-0.0182 x+7.590$ & & 0.86 & 7.6 \\
\hline & \multicolumn{4}{|c|}{ Dry Weight of Shoot (mg) } \\
\hline With & $-0.0107 x+1.7575$ & * & 0.98 & 1.7575 \\
\hline Without & $-0.0085 x+1.5195$ & * & 0.97 & 1.5195 \\
\hline
\end{tabular}

*Significant at $5 \%$ probability.

Table 8. Results of the accelerated aging test (AA) and shoot length (SL) for two lots of rice seedlings with and without amino acid treatment and subjected to different concentrations of sodium chloride.

\begin{tabular}{ccc}
\hline Amino acid & AA $(\%)$ & SL $(\mathrm{cm})$ \\
\hline With & $78 \mathrm{~A}^{1}$ & $2.0 \mathrm{~A}$ \\
Without & $77 \mathrm{~B}$ & $1.8 \mathrm{~B}$ \\
\hline C.V. $(\%)$ & 3.0 & 12.3 \\
\hline
\end{tabular}

1 Means followed by the same capital letter in columns within each concentration do not differ by test $\mathrm{t}(\mathrm{p} \leq 0.05)$.

Table 9. Regression Analysis of the shoot length of two lots of rice seedlings with and without amino acid treatment and subjected to different concentrations of sodium chloride.

\begin{tabular}{|c|c|c|c|c|}
\hline Salt Concentration & $\begin{array}{c}\text { Equation } \\
\mathrm{Y}= \pm a \mathrm{x}^{3} \pm b \mathrm{x}^{2} \pm \mathrm{cx} \pm \mathrm{d}\end{array}$ & $\begin{array}{c}\mathrm{P} \\
\left(\mathrm{b}_{\mathrm{ix}}\right)\end{array}$ & $\mathrm{R}^{2}$ & $\begin{array}{c}\mathrm{Y} \\
\text { Expected }\end{array}$ \\
\hline \multicolumn{5}{|c|}{ Shoot Length $(\mathrm{cm})$} \\
\hline $\mathrm{NaCl}(\mathrm{mM})$ & $-0.0153 x+2.6549$ & $*$ & 0.98 & 2.7 \\
\hline
\end{tabular}

*Significant at $5 \%$ probability.

The amino acids can be used as a tool to assist the plants when they are under adverse conditions, and the application via seed treatment can stimulate root growth (LANA et al., 2009), as well as acting in the rapid establishment of seedlings under unfavorable conditions (CARVALHO et al., 2013). Santos and Vieira, (2005), worked with different doses of commercial product in seeds treatment of Gossypium hirsutum L., and observed an increase of leaf area percentage of the initial emergence and growth of seedlings in proportion to the increase in dose of the product.

Likewise, Skopelitis et al. (2006), evaluating plant Nicotiana tabacum L. and Vitis vinifera $\mathrm{L}$. observed induction of some amino acids when the plants were subjected to salt stress, especially the glutamate dehydrogenase (GD), and these factors of extreme importance, since the work these amino acids minimizes stress conditions (LEA et al., 2007).

The results showed that rice seeds treated with amino acids performed better under salt stress compared to seeds without amino acid. Amino acids accelerate translocation in plants (RHODES; HANDA, 1993), promoting rapid metabolism and increasing enzyme activity reflected in $\mathrm{N}$ metabolism and greater accumulation of assimilates. This may explain why treatment with amino acid produced better results in most of the variables analyzed in both batches of seed. Because treatment with amino acids improves seed performance, and due to the difficulties in determining their modes of 
action on plants (CASTRO et al. 2008), research on these compounds should be done to better establish their efficiency in agricultural production.

\section{CONCLUSION}

Seed treatment with amino acids results in better physiological performance of rice seeds when subjected to salt stress, which affects negatively the physiological quality of seeds.

RESUMO: O estresse salino em plantas de arroz afeta o crescimento, o desenvolvimento e a produtividade da cultura. Sendo assim, o tratamento de sementes pode constituir uma tecnologia, para diminuir os efeitos deletérios causados pelo estresse salino. A utilização de aminoácidos se difundiu muito, tanto na agricultura brasileira quanto em outros países, devido aos benefícios proporcionados às plantas por meio do fornecimento de substâncias orgânicas que resultam em maiores produtividades e conferem melhor qualidade nas diversas culturas. Nesse contexto, o objetivo desta pesquisa foi avaliar o efeito da aplicação de aminoácidos, via tratamento de sementes, no potencial fisiológico de lotes de sementes de arroz submetidos ao estresse salino. O delineamento experimental utilizado foi inteiramente casualizado em esquema fatorial AxBxC (Fator A- Lote 1 e Lote 2; Fator B- Com aminoácido e sem aminoácido; Fator C- concentrações salinas: 0, 25, 50, 75 e $100 \mathrm{mM}$ ), com quatro repetições. A qualidade fisiológica das sementes foi avaliada pelos testes de germinação, primeira contagem da germinação, teste de frio, envelhecimento acelerado, comprimento da parte aérea e raiz e massa seca da parte aérea e raiz. Conclui-se que o tratamento de sementes com aminoácidos proporciona melhor desempenho fisiológico de sementes de arroz quando submetidas a estresse salino, que afeta negativamente a qualidade fisiológica.

PALAVRAS-CHAVE: Oryza sativa L. Qualidade fisiológica. Recobrimento. Salinidade.

\section{REFERENCES}

AJINOMOTO FERTILIZANTES. Produza mais e melhor. Disponível em:

$<$ http://www.ajinomotofertilizantes.com.br/produtos/fertilizantes-liquidos-foliares/amino-plus/>. Acesso em: 10 set. 2013.

ALBUQUERQUE, T. C. S.; DANTAS, B. F. Efeito da aplicação foliar de aminoácidos na qualidade de uvas Benitaka. In: REUNIÃO BRASILEIRA DE FERTILIDADE DO SOLO E NUTRIÇÃO DE PLANTAS, 25; REUNIÃO BRASILEIRA SOBRE MICORRIZAS, 9; SIMPÓSIO BRASILEIRO DE MICROBIOLOGIA DO SOLO, 7; REUNIÃO BRASILEIRA DE BIOLOGIA DO SOLO, 4, 2002, Rio de Janeiro. Resumos... Rio de Janeiro: SBCS; SBM, 2002. p. 44-46.

BAYS, R.; BAUDET, L.; HENNING, A. A.; LUCCA FILHO, O. Recobrimento de sementes de soja com micronutrientes, fungicida e polímero. Revista Brasileira de Sementes, Pelotas, v. 29, n. 2, p. 60-67, 2007. http://dx.doi.org/10.1590/S0101-31222007000200009

BENITEZ, L. C.; PETERS, J. A.; BACARIN, M. A.; KOPP, M. M.; DE OLIVEIRA, A. C.; DE MAGALHÃES JUNIOR, A. M.; BRAGA, E. J. B. Tolerância à salinidade avaliada em genótipos de arroz cultivados in vitro. Ceres, Viçosa, v. 57, n. 3, p. 330-337, 2010.

BRANDÃO, R. P. Importância dos Aminoácidos na agricultura sustentável. Informativo Bio Soja, São Joaquim da Barra, inf. 5, p. 6-8, 2007.

BRASIL. Ministério da Agricultura, Pecuária e Abastecimento. Regras para análise de sementes. Ministério da Agricultura, Pecuária e Abastecimento. Secretaria de Defesa Agropecuária. Brasília, DF: Mapa/ACS, 2009. 395p.

CARVALHO, T. C. D.; SILVA, S. S. D.; SILVA, R. C. D.; PANOBIANCO, M.; MÓGOR, Á. F. Influência de bioestimulantes na germinação e desenvolvimento de plântulas de Phaseolus vulgaris sob restrição hídrica.

Revista de Ciências Agrárias, Recife, v. 36, n. 2, p. 199-205, 2013. 
CASTRO, P. R. C.; SERCILOTO, C. M.; PEREIRA, M. A.; RODRIGUES, J. L. M. Utilização de fosfitos e potencial de aplicação dos aminoácidos na agricultura tropical. Piracicaba: ESALQ, DIBD, 2008. 71p. (Série Produtor Rural, 38).

CASTRO, P. R. C; GONÇALVES, M. R.; CATO, S. C. Efeitos da aplicação foliar de Codamin e de Brassinolide em feijoeiro. Revista de Agricultura, Piracicaba, v. 81, n. 1, p. 24-30, 2006.

CÍCERO, S. M.; VIEIRA, R. D. Teste de frio. In: VIEIRA, R. D.; CARVALHO, N. M. (Ed.) Testes de vigor em sementes. Jaboticabal: FUNEP, 1994. p. 151-164.

COMPANHIA NACIONAL DE ABASTECIMENTO. Acompanhamento da safra brasileira de grãos: v.1Safra 2013/14, n.3- Terceiro Levantamento, dezembro 2013. Disponível em:

<http://www.conab.gov.br/OlalaCMS/uploads/arquivos/14_01_10_10_12_36_boletim_portugues_dezembro_2 013.pdf>. Acesso em: 5 fev. 2014.

DEUNER, C.; MAIA, M. S.; DEUNER, S.; ALMEIDA, A. S.; MENEGHELLO, G. E. Viabilidade e atividade antioxidante de sementes de genótipos de feijão-miúdo submetidos ao estresse salino. Revista Brasileira de Sementes, Londrina, v. 33, n. 4, p. 711-720, 2011. http://dx.doi.org/10.1590/S0101-31222011000400013

DINIZ, K. A.; OLIVEIRA, J. A; GUIMARÃES, R. M.; CARVALHO, M. L. M; MACHADO, G. C. Incorporação de microrganismos, aminoácidos, micronutrientes e reguladores de crescimento em sementes de alface pela técnica de peliculização. Revista Brasileira de Sementes, Pelotas, v. 28, n. 3, p. 37-43, 2006.

DINIZ, K. A.; SILVA, P. A.; VEIGA, A. D.; ALVIM, P. O.; OLIVEIRA, J. A. Qualidade fisiológica e atividade enzimática de sementes de alface revestidas com diferentes doses de micronutrientes, aminoácidos e reguladores de crescimento. Revista Ciência Agronômica, Fortaleza, v. 38, n. 4, p. 396-400, 2007. http://dx.doi.org/10.1590/s0101-31222006000300006

DUARTE, G. L; LOPES, N. F.; MORAES, D. M.; SILVA, R. N. Physiological quality of wheat seeds submitted to saline stress. Revista Brasileira de Sementes, Pelotas, v. 28, n. 1, p. 122-126, 2006. http://dx.doi.org/10.1590/S0101-31222006000100017

FLOSS, E. L.; FLOSS, L. G. Fertilizantes organo minerais de última geração: funções fisiológicas e uso na agricultura. Revista Plantio Direto, Passso Fundo, v. 100, n. 1, p. 26-29, 2007.

GARCIA, G. O.; FERREIRA, P. A.; MIRANDA, G. V.; OLIVEIRA, F. G.; SANTOS, D. B. Índices fisiológicos, crescimento e produção do milho irrigado com água salina. Irriga, Botucatu, v. 12, n. 3, p. 307325, 2007.

GUSTAFSON, D. J.; GIBSON, D. J.; NICKRENT, D. L. Competitive relationships of Andropogon gerardii (Big Bluestem) from remnant and restored native populations and select cultivated varieties. Functional Ecology, London, v. 18, n. 3, p. 451-457, 2004. http://dx.doi.org/10.1111/j.0269-8463.2004.00850.x

KIKUTI, H.; TANAKA, R. T. Produtividade e qualidade de sementes de feijão em função da aplicação de aminoácidos e nutrientes. In: CONGRESSO NACIONAL DE PESQUISA DE FEIJÃO, 8, 2005, Goiânia. Anais... Santo Anônio de Goiás: EMBRAPA, 2005. v. 2, p. 1062-1065.

LANA, A. M. Q.; LANA, R. M. Q.; GOZUEN, C. F.; BONOTTO, I. E; TREVISAN, L. R. Aplicação de regulado $\neg$ res de crescimento na cultura do feijoeiro. Bioscience Journal, Uberlândia, v. 25, n. 1, p. 13-20, 2009.

LARCHER, W. Ecofisiologia vegetal. 1. ed. São Carlos: Rima, 2000. 531p

LEA, P. J.; SODEK, L.; PARRY, M. A. J.; SHEWRY, P. R. E; HALFORD, N. G. Asparagine in plants. Annals of Applied Biology, v. 150, n. 1, p. 1-26, 2007. http://dx.doi.org/10.1111/j.1744-7348.2006.00104.x 
LIMA, M. G. S. Detecção de genes e expressão enzimática em cultivares de arroz (Oryza sativa L.) crescidas sob estresse salino. 2008. 93f. Tese (Doutorado em Ciências) - Fisiologia vegetal, Departamento de Botânica, Universidade Federal de Pelotas.

LIMA, M. G. S.; LOPES, N. F.; MORAES, D. M.; ABREU, C. M. Qualidade fisiológica de sementes de arroz submetidas a estresse salino. Revista Brasileira de Sementes, Londrina, v. 27, n. 1, p. 54-61, 2005. http://dx.doi.org/10.1590/S0101-31222005000100007

LUZ, J. M. Q.; OLIVEIRA, G.; QUEIROZ, A. A.; CARREON, R. Aplicação foliar de fertilizantes organominerais em cultura de alface. Horticultura Brasileira, Brasília, v. 28, n. 3, p. 373-377, 2010. http://dx.doi.org/10.1590/S0102-05362010000300023

MACHADO NETO, N.; CUSTÓDIO, C. C.; COSTA, P. R.; DONÁ, F. L. Deficiência hídrica induzida por diferentes agentes osmóticos na germinação e vigor de sementes de feijão. Revista Brasileira de Sementes, Pelotas, v. 28, n. 1, p. 142-148, 2006. http://dx.doi.org/10.1590/S0101-31222006000100020

MARCOS FILHO, J. Testes de vigor: importância e utilização. In: KRZYZANOWSKI, F. C., VIEIRA R. D. (Eds.). Vigor de sementes: Conceitos e testes. Londrina, ABRATES, cap. 3, p. 3-24, 1999.

MORAES, G. A. F.; DE MENEZES, N. L.; PASQUALLI, L. L. Comportamento de sementes de feijão sob diferentes potenciais osmóticos. Ciência Rural, Santa Maria, v. 35, n. 4, p. 776-780, 2005. http://dx.doi.org/10.1590/S0103-84782005000400004

NAKAGAWA, J. Testes de vigor baseados no desempenho das plântulas. In: KRZYZANOWSKI, F. C.; VIEIRA, R. D.; FRANÇA-NETO, J. B. (Eds.). Vigor de sementes: conceitos e testes. Londrina: ABRATES, cap. 2, p. 9-13. 1999.

NUNES, J. C. Tratamento de semente - qualidade e fatores que podem afetar a sua performance em laboratório. Syngenta Proteção de Cultivos Ltda. 2005. 16p.

PRIYACHEM. Ankur. Disponível em: <http://www.priyachem.com/ankur.htm>. Acesso em: 9 fev. 2014. $2014 \mathrm{~b}$

PRIYACHEM. Technical e scientifc data. Amino-acids as plant nutrients for foliar spray and fertigation, 2014a.

RHODES A. S., HANDA S. 1989. Amino acid metabolism in relation to osmotic adjustment in plant cell. In: Cherry, J. H. (Ed), Environmental stress in plants, p. 41-62. http://dx.doi.org/10.1007/978-3-642-73163-1_6

ROSSETTI, M. L. R. A célula e seus constituintes moleculares. In: ZAHA, A.; PASSAGLIA, L. M. P.; FERREIRA, H. B. Biologia Molecular Básica. 4. ed. Porto Alegre (RS): ARTMED, Cap. 1, p. 4-14, 2012.

TORRES, S. B.; VIEIRA, E. L.; MARCOS FILHO, J. Efeitos da salinidade na germinação e no desenvolvimento de plântulas de pepino. Revista Brasileira de Sementes, Brasília, v. 22, n. 2, p. 39-44, 2000. http://dx.doi.org/10.17801/0101-3122/rbs.v22n2p39-44

USDA - UNITED STATES DEPARTMENT OF AGRICULTURE. Disponível em: <http://www.fas.usda. gov/psdonline/psdQuery.aspx>. Acesso em: 27 mar. 2013.

VAN NGUYEN, N.; FERRERO, A. Meeting the challenges of global rice production. Paddy and Water Environment, Japão, v. 4, n. 1, p. 1-9, 2006. 